Georgia State University College of Law Reading Room

$1-1-2012$

\title{
Unintended Consequences: The Impact of the Court's Recent Cases on Structural Ineffective Assistance of Counsel Claims
}

Lauren Sudeall Lucas

Georgia State University College of Law, lslucas@gsu.edu

Follow this and additional works at: https://readingroom.law.gsu.edu/faculty_pub

Part of the Constitutional Law Commons, Criminal Law Commons, Criminal Procedure Commons, and the Supreme Court of the United States Commons

\section{Recommended Citation}

Lauren Sudeall Lucas, Unintended Consequences: The Impact of the Court's Recent Cases on Structural Ineffective Assistance of Counsel Claims, 25 Fed. Sent'g Rep. 106 (2012).

This Article is brought to you for free and open access by the Faculty Publications at Reading Room. It has been accepted for inclusion in Faculty Publications By Year by an authorized administrator of Reading Room. For more information, please contact mbutler@gsu.edu. 


\section{Unintended Consequences: The Impact of the Court's Recent Cases on Structural Ineffective Assistance of Counsel Claims}

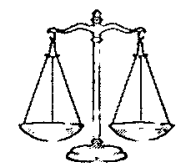

\section{LAUREN SUDEALL LUCAS*}

Assistant Professor of Law, Georgia

State University

College of Law
Advocates seeking indigent defense reform have often relied on civil litigation to prospectively enforce the Sixth Amendment right to counsel and to attack structural deficiencies of indigent defense systems-such as underfunding - that are likely to lead to system-wide ineffective assistance. Although the United States Supreme Court has addressed myriad aspects of postconviction ineffective assistance of counsel claims made in the criminal context, particularly in the last decade or so, ${ }^{1}$ many of these cases have had little direct bearing on the way in which advocates have attempted to enforce the Sixth Amendment in the civil context. The Supreme Court has never directly addressed structural ineffective assistance of counsel claims or the standard that should be applied to such claims.

The Court's most recent cases in its right to counsel line of jurisprudence are no different in that they address neither civil right to counsel claims nor prospective enforcement of the Sixth Amendment. However, the way in which they redefine the Sixth Amendment's relevance pretrial and their pragmatic approach to criminal justice issues may have the unintended effect of paving an easier road to the vindication of structural claims in the civil context.

\section{Treatment of Structural Ineffective Assistance Claims in the Civil Context}

The theory underlying civil claims alleging structural violations of the right to counsel is typically that systemic deficiencies present throughout a public defense systemwhich may include inadequate resources, delays in the appointment of counsel, inadequate attorney supervision, or crushing public defender caseloads-deny indigent defendants their right to counsel (or to the effective assistance of counsel) in violation of the Sixth Amendment. Such claims are often brought as class action lawsuits, banding together all indigent defendants who have been charged or who will be charged in the future with criminal offenses that make them eligible for incarceration (but who have not yet been convicted or sentenced), thus subjecting them to the indigent defense system at issue now or sometime in the future. The aim in such cases is to show that the indigent defense system is so inherently dysfunctionaland the flaws of that system so universally apparent- that any indigent defendant subject to that system is likely to receive ineffective assistance, regardless of the other factors present in his or her individual criminal case.

Given the difference in posture and nature between these claims and postconviction ineffective assistance claims raised in the criminal context, courts faced with such claims have had to decide what standard to apply. In the criminal context, courts have typically analyzed ineffective assistance of counsel claims by applying the standard set forth in Strickland $v$. Washington, ${ }^{2}$ asking whether counsel's conduct was deficient (i.e., was it reasonable under prevailing professional norms) and whether the defendant was prejudiced by such conduct (i.e, but for counsel's deficient conduct, is there a reasonable probability that the outcome of the proceeding would have been different). ${ }^{3}$

In contrast, many of the courts analyzing prospective claims of ineffective assistance in the civil context have eschewed that standard in favor of a different standard. The dominant approach to such claims is set forth in Luckey $v$. Harris, ${ }^{4}$ a case decided by the Eleventh Circuit Court of Appeals. ${ }^{5}$ Because the plaintiffs in Luckey were seeking prospective enforcement of their Sixth Amendment right to counsel, the Luckey court applied the standard used to assess claims for injunctive relief, requiring plaintiffs to demonstrate "the likelihood of substantial and immediate irreparable injury, and the inadequacy of remedies at law." 6 The Luckey court and others following in its stead have expressly rejected the application of the Strickland standard to this context, reasoning that the factors favoring deferential analysis of counsel's performance in the postconviction context-"concerns for finality, concern that extensive post-trial burdens would discourage counsel from accepting cases, and concern for the independence of counsel"do not apply where prospective relief is being sought.?

\section{The Court's Broader Conception of the Right to Counsel and Its Implications for Structural Claims} The Court's recent Sixth Amendment cases do not address either systemic or prospective claims, but their approach to the Sixth Amendment's right to counsel does indirectly provide some encouragement for civil plaintiffs litigating structural ineffectiveness claims. In particular, the Court's recognition that the right to counsel is not equated with the

Federal Sentencing Reporter, Vol. 25, No. 2, pp. 106-I09, ISSN 1053-9867, electronic ISSN 1533-8363. (C) 2012 Vera Institute of Justice. All rights reserved. Please direct requests for permission to photocopy or reproduce article content through the University of California Press's Rights and Permissions website, http://www.ucpressjournals.com/reprintInfo.asp. DOI: I0.I525/fsr.2012.25.2.106. 
right to a fair trial (and, as a result, we can conceive of Sixth Amendment harm or injury that may not relate to the trial or trial outcomes), the Court's willingness to recognize specific pretrial duties that counsel must fulfill, and the Court's pragmatic approach to the functioning of the criminal justice system, are all helpful to plaintiffs attempting to show that structural deficiencies are likely to lead to Sixth Amendment violations in the future.

In Missouri v. Frye, ${ }^{8}$ the Court held that counsel's failure to inform his client of a favorable plea offer constituted ineffective assistance of counsel. ${ }^{9}$ In doing so, the Court made the important holding-necessary to its analysis in Lafler v. Cooper, ${ }^{\text {IO }}$ decided the same day-that the right to counsel extends to the negotiation and consideration of plea offers that lapse or are rejected. ${ }^{\text {II }}$ In Lafler, the Court held that the petitioner had been prejudiced by counsel's deficient performance in erroneously advising the petitioner to reject a pending plea offer and proceed to trial (following trial, the petitioner had been convicted and sentenced accordingly). ${ }^{12}$ Ultimately, the Lafler Court rejected the government's position that "[a] fair trial wipes clean any deficient performance by defense counsel during plea bargaining." ${ }^{3}$

First and foremost, these recent Court holdings establish that the right to counsel guarantees more than just the right to a fair trial. ${ }^{\mathrm{I}}$ Perhaps the most significant contribution of Lafler and Frye to Sixth Amendment jurisprudence is that they have redefined the Sixth Amendment as focused not solely on the reliability of the ultimate verdict and the fairness of the trial itself, but instead on the procedural fairness of the adversarial process preceding the trial. ${ }^{15}$ This key aspect of their holdings is relevant to structural ineffective assistance claims in two ways. First, it emphasizes the importance of enforcing the right to counsel not only in relation to the trial, but in relation to all of the "critical stages" preceding it. ${ }^{16}$ In other words, the Court is concerned not just with counsel's ability to effectively perform aspects of representation that will bear directly on issues of guilt or innocence or that will have a direct bearing on the trial, but further requires effective assistance with regard to any pretrial duty performed during a "critical stage." Second, it reconceives the range of "outcomes" that may be relevant under the Strickland standard, making it possible for a defendant to demonstrate ineffective assistance not only by demonstrating that counsel's deficient conduct made his conviction more likely than not, but also by demonstrating that had counsel provided effective assistance at an earlier critical stage, there is a reasonable probability that the outcome of that stage itself would have been different. For example, although errors committed by counsel during voir dire allowing biased jurors on the jury or the failure to challenge racially motivated strikes by the prosecution may not undermine the ultimate reliability of the trial, under the Lafler and Frye approach, the defendant need not demonstrate an effect on the ultimate finding of guilt, but may instead demonstrate that but for counsel's deficient conduct, there is a reasonable probability that he would have been tried by a different jury. ${ }^{17}$ By broadening the right to counsel's scope of applicability and the means by which ineffective assistance can be demonstrated, these decisions provide civil plaintiffs with a broader definition of potential injury, expanding both when and how it might occur and thus the number of ways in which structural deficiencies might lead to its potential infliction.

In making this leap, the Lafler-Frye Court did not go so far as to eliminate Strickland's prejudice requirement; the Court was very clear in confining itself to Strickland's twoprong inquiry. In that respect, it cannot provide any clear support for the inapplicability of that standard in the prospective enforcement context, nor can it provide anything but very indirect support for the idea that Strickland's prejudice requirement should not apply at all to prospective claims for relief. ${ }^{18}$ The Court was very clear, however, that it values not only that conduct of counsel which bears on the outcome of the trial itself or on the specific question of guilt, but also that conduct which "undermine[s] the proper functioning of the adversarial process" and that "which cause[s] the defendant to lose benefits he would have received in the ordinary course but for counsel's ineffective assistance." ${ }^{19}$ So, the definition of possible injury resulting from counsel's deficient conduct is no longer limited solely to conviction or a harsher sentence; instead, it may take a variety of forms, including the missed opportunity to accept a plea offer. Translated to the civil context, where an indigent defendant-plaintiff must demonstrate "the likelihood of substantial and immediate irreparable injury" to prove a prospective claim for relief, a plaintiff need no longer demonstrate that systemic deficiencies would make conviction more likely than not, but instead has a broader range of outcomes on which to measure the effect of counsel's potential shortcomings. Whereas it may be difficult for civil claimants to draw a direct connection between systemic deficiencies and trial outcomes, given the myriad factors that may intervene in the interim, it will be a less daunting task for those same claimants to demonstrate how systemic deficiencies will inevitably result in missed opportunities or "los[t] benefits"-such as missed filing deadlines or the failure to file specific pretrial motionsresulting from a lack of time or resources.

Additionally, in these and other recent cases, the Court has demonstrated a willingness to indirectly impose prospective duties on counsel during pretrial proceedings. At the very least, the Court has recognized that a fair trial cannot substitute for duties that go unfulfilled pretrial, and that when specific duties are not fulfilled, the Court will make a de facto finding of deficient performance. Although not a severe departure from past precedent, this does cut back some on the view expressed in Strickland that "the proper measure of attorney performance remains simply reasonableness under prevailing professional norms" and that " $[\mathrm{m}]$ ore specific guidelines are not appropriate. . . ."20 For example, in Padilla v. Kentuck,, ${ }^{21}$ the Court held that counsel has a duty to advise her client of the collateral 
consequences of a guilty plea, ${ }^{22}$ and in Missouri v. Frye, ${ }^{23}$ the Court held that defense counsel has a duty to communicate to her client the terms of a plea offer made by the prosecution. ${ }^{24}$ In earlier cases, like Wiggins $v$. Smith ${ }^{25}$ and Rompilla $v$. Beard, ${ }^{26}$ the Court made clear defense counsel's responsibility to conduct pretrial mitigation investigation in capital cases. Thus, the Court has provided some recognition, albeit in limited circumstances, that the effective assistance of counsel can in some respects be boiled down to discrete duties that counsel must fulfill in every case. These duties-some of which the Court has already imposed and others that it easily could in future cases-are often made impossible by structural deficiencies, such as severe underfunding or public defenders carrying crushing caseloads. The further the Court continues down this path of identifying specific pretrial duties-by finding the failure to fulfill the duty adequate grounds for deficient performance--and to the extent systemic deficiencies make any of these duties all but impossible to fulfill, it will be a much clearer path toward arguing that those deficiencies lead to an increased "likelihood of substantial and immediate irreparable injury."

Last, the Court's recent opinions in this area have taken a pragmatic rather than formalist approach to enforcing the right to counsel. In Frye, the Court recognized that, given the centrality of plea bargaining, "[i]n today's criminal justice system ... the negotiation of a plea bargain, rather than the unfolding of a trial, is almost always the critical point for a defendant." 27 Similarly, in Lafler, the Court acknowledged the "reality" that most criminal cases are resolved by pleas, and that for the right to effective assistance to have any force, it would have to have real meaning in the plea bargaining context. ${ }^{28}$ In Maples $v$. Thomas, ${ }^{29}$ the Court reasoned that a capital defendant who is represented by counsel in name only may, as a practical matter, have been abandoned by counsel for purposes of overcoming procedural default. ${ }^{30}$ That same pragmatism would be welcomed in the civil context where courts may be making decisions about whether, in practice, a lawyer who is paid a nominal sum to handle a criminal case or appeal would be in any position to offer effective assistance, or whether a system that drastically undercompensates attorneys will be able to attract competent counsel or counsel who can afford to spend the requisite amount of time on their appointed (vs. private) cases. For example, in Simmons $v$. State Public Defender, ${ }^{3 \mathrm{I}}$ the Iowa Supreme Court held that a \$1500 fee cap on court-appointed appeals "would in many cases substantially undermine the right of indigents to the effective assistance of counsel." 32 In reaching this conclusion, the court reasoned that a lawyer working under such a fee system would find it difficult to make a living, that the fee cap would have a chilling effect on qualified lawyers accepting such appointed cases, and that paying such a low fee for appointed cases would pit a lawyer's economic interests against the client's interest in effective representation. ${ }^{33}$ To the extent the Court's reasoning in its more recent cases encourages other courts to adopt a similarly pragmatic view in giving meaning to the Sixth Amendment-for example, by recognizing that counsel cannot fulfill certain duties without access to adequate resourcesit will benefit indigent defendants litigating civil right to counsel claims.

\section{Conclusion: An Easier Road Ahead for Civil Claimants?}

In the wake of the Supreme Court's last term, it is likely that many will focus on Lafler and Frye's capability to expand the universe of possible criminal ineffective assistance of counsel claims. Their lesser considered impact may be on structural right to counsel claims and the way in which the Court's reasoning provides civil claimants with additional ways in which to establish their entitlement to prospective relief based on systemic deficiencies.

The Court is unlikely to chime in about the appropriate standard to be applied in these cases, and its blind adherence to the Strickland framework may make it difficult to conceive of it endorsing Strickland's total abandonment, even in the civil context. But, its evolved understanding of the Sixth Amendment-its reach, its applicability to the pretrial context, and its ability to articulate specific pretrial duties of counsel-will be helpful nonetheless to civil claimants needing to show a link between system-wide deficiencies and the likelihood that counsel will not be in a position to provide effective assistance in the future.

The right to counsel that exists in the wake of Lafler and Frye is a more robust version of the pretrial right to counsel, broadening the range of opportunities for defendants to enforce that right and the means by which counsel's pretrial effectiveness may be assessed. The Court's demonstrated willingness to depart from a purely trial-centered definition of Sixth Amendment injury, to expect a certain level of conduct from counsel even when that conduct does not bear on the trial itself, and to take a more pragmatic approach to effectuate the Sixth Amendment right suggests an easier path for indigent defendants hoping to vindicate their right to counsel through structural challenges made in the civil context.

\section{Notes}

* I am grateful to Courtney Anderson, Russell Covey, Caren Myers Morrison, and Nirej Sekhon for their thoughtful comments.

1 See, e.g., Missouri v. Frye, 132 S. Ct. 1399 (2012); Lafler v. Cooper, 132 S. Ct. 1376 (2012); Padilla v. Kentucky, 130 S. Ct. 1473 (2010); Rompilla v. Beard, 545 U.S. 374 (2005); Wiggins v. Smith, 539 U.S. 510 (2003); Williams v. Taylor, 529 U.S. 362 (2000).

2 Strickland v. Washington, 466 U.S. 668 (1984).

3 ld. at $687-88,694$.

4 Luckey v. Harris, 860 F.2d 1012 (11 th Cir. 1988).

5 The Constitution Project, Nat'l Right to Counsel Comm., Jus. tice Denied: America's Continuing Neglect of Our Constitutional Right to Counsel at 112 (2009), available at http://www.constitutionproject.org/manage/file/139.pdf; see also, e.g., Lavallee v. Justices in Hampden Superior Court, 812 N.E.2d 895, 905 (Mass. 2004); New York County Lawyers' Association v. State of New York, 294 A.D.2d 69, 74 (N.Y.A.D. 1 
Dept. 2002); Rivera v. Rowland, 1996 WL 636475 , at *5 (Conn. Super. Oct. 22, 1996) (all applying Luckey standard).

6 Luckey, 860 F.2d at 1017-18.

7 Id. at 1017; see also, e.g., Simmons v. State Public Defender, 791 N.W.2d 69 (lowa 2010).

8 Frye, 132 S. Ct. 1399 (2012).

9 Id. at 1408.

10 Lafler, 132 S. Ct. 1376 (2012).

11 Frye, 132 S. Ct. at 1406-08.

12 Lafler, 132 S. Ct. at $1388-91$

13 ld. at 1388.

14 Id.; see also Justin F. Marceau, Embracing a New Era of Ineffective Assistance of Counsel, $14 \mathrm{U}$. Pa. J. Const. L. 1161, 1182 (2012) (noting that an "established line of cases and scholar. ship that supports the view that the right to counsel serves goals beyond safeguarding against trial unfairness or verdict reliability").

15 ld. (" $[\mathrm{H}]$ ere the question is not the fairness or reliability of the trial, but the fairness and regularity of the processes that preceded it.").

16 ld. at 1385 (reiterating that that all criminal defendants have the right to the effective assistance of counsel at every "critical stage" of the proceedings, including those that occur pre-trial).

17 Marceau, supra note 14 , at 1194-1200.

18 Given that the prejudice requirement in Strickland stems largely from due process, it would seem that as the focus on fair results decreases, so too would the need for a prejudice requirement. Cf. United States v. Gonzalez.Lopez, 548 U.S. 140, 147 (2006) (Scalia, J., dissenting) (explaining that early cases defining the right to counsel as the right to the effective assistance of counsel were based on the Due Process Clause's entitlements to a fair trial and just results).

19 Lafler, 132 S. Ct. at 1388.

20 Strickland, 466 U.S. at 688 .

21 Padilla v. Kentucky, 130 S. Ct. 1473 (2010).

22 Id. at 1483

23 Frye, 132 S. Ct. 1399 (2012).

24 Id. at 1408 ("This Court now holds that, as a general rule, defense counsel has a duty to communicate formal offers from the prosecution to accept a plea on terms and conditions that may be favorable to the accused.").

25 Wiggins v. Smith, 539 U.S. 510 (2003).

26 Rompilla v. Beard, 545 U.S. 374 (2005).

27 Frye, 132 S. Ct. at 1407 .

28 Lafler, 132 S. Ct. at 1388 ("A fair trial wipes clean any deficient performance by defense counsel during plea bargaining. That position ignores the reality that criminal justice today is for the most part a system of pleas, not a system of trials.") (citing Frye, 132 S. Ct. at 1386); see also Lafler, id. ("[T]he right to adequate assistance of counsel cannot be defined or enforced without taking account of the central role plea bargaining plays in securing convictions and determining sentences.") (citing Frye, 132 S. Ct. at 1386).

29 Maples v. Thomas, 132 S. Ct. 912 (2012).

30 ld. at 924-27.

31 Simmons v. State Public Defender, 791 N.W.2d 69 (lowa 2010).

32 ld. at 87.

33 d. at $87-88$. 